\title{
An Innovative Scaffolding Coupler Design Based on TRIZ Theory
}

\author{
Nanchu Guo ${ }^{1}$ \\ ${ }^{1}$ Suzhou Vocational University, China
}

\begin{abstract}
The purpose for this innovative coupler design is to enhance efficiency for scaffolding install and dissemble. By analyzing ideal solution based on TRIZ theory, the technologic contradiction of this problem can be regarded as "time loss and reliability". According to contradiction matrix, one way to solve the problem is through asymmetric principle. Following this, this paper redesigned the traditional fixed coupler from a two bolts structure to a one bolt structure, thus enhance the efficiency of scaffolding install and dissemble by approximately $100 \%$. The paper also gives product innovative design process based on TRIZ theory. This case shows that TRIZ theory can be used to provide feasible design plans for designers.
\end{abstract}

Keywords-TRIZ; scaffolding coupler; innovative design

\section{BACKGROUND}

Fixed scaffolding Coupler can be used for connecting scaffold tubes with $48 \mathrm{~mm}$ external diameter. Coupler material is malleable cast iron. When a coupler is being used, its internal surface should make tight contact with steel tubes, and the two should be properly fixed by a T-bolt. According to safety regulations of construction scaffolding coupler, tightening torque of the coupler should be "no smaller than 40 N.m and no larger than 65 N.m" and "tighter is not always mean better". The regulation requires the user to "check the tightening torque by a torque wrench" and "retightening the coupler if its torque is unqualifiable". Since there is no relative examine data for tightening levels of couplers, the stability and carrying capacity of the scaffold is difficult to control. In short, fixing by T-bolts is a time and labor-consuming process which might even jeopardize the safety and stability of the scaffold. In order to ensure safety, the coupler should facing inside, the bolt should facing upward and the cross joint should not facing downward. .

\section{BRIEF REVIEW OF TRIZ}

According to Genrich Altshuller, a product, similar to a biological system, will develop and evolve following certain patterns; the principle of invention and innovation is to eliminate technological contradiction; an ideal state of technologic development is to achieve more functions with less resources [1].

TRIZ included a standard problem solving pattern that can be transplanted within multiple areas. It set an ideal target without restrictions before solving the problem, and continuously following this ideal target until a desirable solution is obtained. Theoretic foundation of TRIZ is contradiction (technological contradiction and physical contradiction). Analyzing Tools for problem solving in TRIZ is object-field model and contradiction matrix table. Knowledge database is 40 invention principles and 76 standard problem solving methods
[2]. Main elements and solving methods of TRIZ is shown in figure 1 .

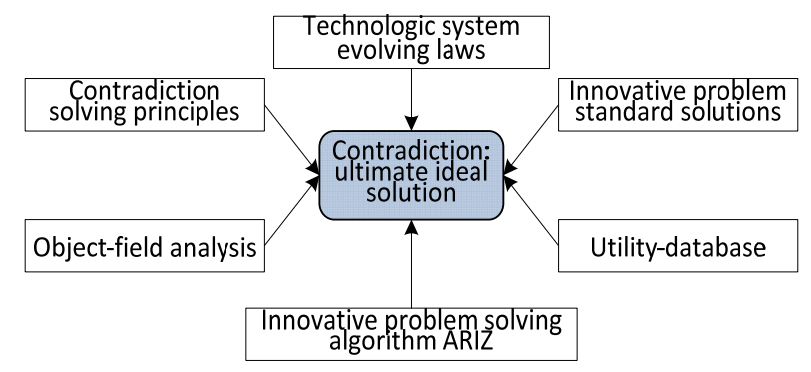

FIGURE I.

MAIN COMPONENTS AND METHODS OF TRIZ

TRIZ theory divided contradiction into three categories: physical contradiction, technologic contradiction and managerial contradiction. Technologic contradiction occurs when two parameters in a technological system are in conflict. That is, improvements on one parameter will lead to deterioration on the other [3].

TABLE I. 39 GENERAL ENGINEERING PARAMETERS

\begin{tabular}{|c|c|c|}
\hline $\begin{array}{l}\text { 1. Weight of moving } \\
\text { object }\end{array}$ & 14. Strength & 27. Reliability \\
\hline $\begin{array}{l}\text { 2. Weight of } \\
\text { stationary object }\end{array}$ & $\begin{array}{l}\text { 15. Duration of action } \\
\text { of moving object }\end{array}$ & $\begin{array}{l}\text { 28. Measurement } \\
\text { accuracy }\end{array}$ \\
\hline $\begin{array}{l}\text { 3. Length of moving } \\
\text { object }\end{array}$ & $\begin{array}{l}\text { 16. Duration of action } \\
\text { by stationary object }\end{array}$ & $\begin{array}{l}\text { 29. Manufacturing } \\
\text { precision }\end{array}$ \\
\hline $\begin{array}{l}\text { 4. Length of } \\
\text { stationary object }\end{array}$ & 17. Temperature & $\begin{array}{l}\text { 30. Object-affected } \\
\text { harmful factors }\end{array}$ \\
\hline $\begin{array}{l}\text { 5. Area of moving } \\
\text { object }\end{array}$ & $\begin{array}{l}\text { 18. Illumination } \\
\text { intensity }\end{array}$ & $\begin{array}{l}\text { 31. Object-generated } \\
\text { harmful factors }\end{array}$ \\
\hline $\begin{array}{l}\text { 6. Area of stationary } \\
\text { object }\end{array}$ & $\begin{array}{l}\text { 19. Use or energy by } \\
\text { moving object }\end{array}$ & $\begin{array}{l}\text { 32. Ease of } \\
\text { manufacture }\end{array}$ \\
\hline $\begin{array}{l}\text { 7. Volume of moving } \\
\text { object }\end{array}$ & $\begin{array}{l}\text { 20. Use of energy by } \\
\text { stationary object }\end{array}$ & 33. Ease of operation \\
\hline $\begin{array}{l}\text { 8. Volume of } \\
\text { stationary object }\end{array}$ & 21. Power & 34. Ease of repair \\
\hline 9. Speed & 22. Loss of Energy & $\begin{array}{l}\text { 35. Adaptability or } \\
\text { versatility }\end{array}$ \\
\hline 10. Force & 23. Loss of substance & 36. Device complexity \\
\hline 11. Stress or pressure & $\begin{array}{l}\text { 24. Loss of } \\
\text { Information }\end{array}$ & $\begin{array}{l}\text { 37. Difficulty of } \\
\text { detecting and easuring }\end{array}$ \\
\hline 12. Shape & 25. Loss of Time & $\begin{array}{l}\text { 38. Extent of } \\
\text { automation }\end{array}$ \\
\hline $\begin{array}{l}\text { 13. Stability of the } \\
\text { object's composition }\end{array}$ & $\begin{array}{l}\text { 26. Quantity of } \\
\text { substance/the matter }\end{array}$ & 39. Productivity \\
\hline
\end{tabular}


The innovative design for the scaffolding coupler in this paper is based on the technologic contradiction method and requires 40 innovative principles and 39 engineering parameters [4].

TABLE II.

40 INNOVATIVE PRINCIPLES

\begin{tabular}{|c|c|c|c|}
\hline 1. Segmentation & $\begin{array}{l}\text { 11. Cushion } \\
\text { in advance }\end{array}$ & $\begin{array}{l}21 . \text { Rushing } \\
\text { through }\end{array}$ & 31. Porous aterials \\
\hline 2. Extraction & $\begin{array}{l}12 . \\
\text { Equipotentiali } \\
\text { ty }\end{array}$ & $\begin{array}{l}\text { 22. Blessing } \\
\text { in disguise }\end{array}$ & 32. Changing color \\
\hline 3. Local quality & 13. Inversion & 23. Feedback & 33. Homogeneity \\
\hline 4. Asymmetry & $\begin{array}{l}14 . \\
\text { Spheroidality } \\
\text { or curvature }\end{array}$ & $\begin{array}{l}24 . \\
\text { Intermediary }\end{array}$ & $\begin{array}{l}\text { 34. Discarding, } \\
\text { recycling, and } \\
\text { regenerating }\end{array}$ \\
\hline 5. Combination & 15. Dynamics & $\begin{array}{l}25 . \text { Self- } \\
\text { service }\end{array}$ & $\begin{array}{l}\text { 35. Transforming } \\
\text { physical or } \\
\text { chemical properties }\end{array}$ \\
\hline 6. Universality & $\begin{array}{l}\text { 16. Partial or } \\
\text { excessive } \\
\text { action }\end{array}$ & 26. Copying & 36. Phase transition \\
\hline 7. Nesting dolls & $\begin{array}{l}\text { 17. Another } \\
\text { dimension }\end{array}$ & $\begin{array}{l}\text { 27. Cheap } \\
\text { disposables }\end{array}$ & $\begin{array}{l}\text { 37. Thermal } \\
\text { expansion }\end{array}$ \\
\hline 8. Counterweight & $\begin{array}{l}18 . \\
\text { Mechanical } \\
\text { vibration }\end{array}$ & $\begin{array}{l}28 . \\
\text { Replacement } \\
\text { of mechanical } \\
\text { systems }\end{array}$ & 38. Strong oxidants \\
\hline $\begin{array}{l}\text { 9. Prior } \\
\text { counteraction }\end{array}$ & $\begin{array}{l}\text { 19. Periodic } \\
\text { action }\end{array}$ & $\begin{array}{l}29 . \\
\text { Pneumatics } \\
\text { or hydraulics }\end{array}$ & $\begin{array}{l}\text { 39. Inert } \\
\text { environment }\end{array}$ \\
\hline 10. Prior action & $\begin{array}{l}\text { 20. Continuity } \\
\text { of useful } \\
\text { action }\end{array}$ & $\begin{array}{l}\text { 30. Porous } \\
\text { materials }\end{array}$ & $\begin{array}{l}\text { 40. Composite } \\
\text { materials }\end{array}$ \\
\hline
\end{tabular}

\section{INNOVATIVE DESIGN FOR FIXED SCAFFOLDING COUPLER}

\section{A. Problem Description}

Traditional fixed coupler used two bolts to fix two tubes respectively as shown in figure 2 . The installing and disassembling processes are time-consuming and will delay the whole construction. Furthermore, an additional bolt normally means additional threat to safety. In addition, the joint quality is highly dependent on the quality of couplers and operations of users. Thus, it is necessary to make an innovative design for fixed couplers.

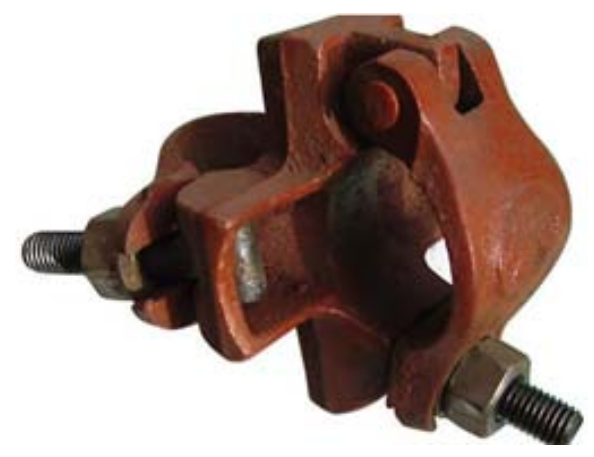

FIGURE II.

TRADITIONAL FIXED SCAFFOLDING COUPLER

\section{B. Ideal Solution for the Product}

Step 1: what is the ultimate goal of the design: rapid installing and dissembling
Step 2: what is the ideal solution: no time needed to install or dissemble the scaffolds

Step 3: what are the obstructions for achieving the ideal solution: two bolts need to be screwed in or out when installing or dissembling

Step 4: why they became obstructions: it is time-consuming for screwing in/out two bolts especially for safety concerns

Step5: how to decrease or eliminate the effects of the obstructions: better designing the coupler to reduce needed bolt numbers, or changing the fixing method of bolts

Step 6: what resources can be helpful: coupler structure, other fixing methods

Step 7: is there any exist tools or methods in other areas can be helpful: have not found yet

A quantitative equation for judging ideal levels for the innovative designs can be given as the following:

$$
\mathrm{I}=\frac{\sum B}{\sum C+\sum H}
$$

where I represents ideal level, $\sum B$ is aggregate benefits, $\sum C$ is aggregate costs, and $\sum H$ is aggregate harm.

As in (1), five ways will increase the ideal level:

increase numerator and decrease denominator

increase numerator and keep denominator unchanged

keep numerator unchanged and decrease denominator

increase both, but with a higher rate for numerator

decrease both, but with a lower rate for numerator

\section{Contradiction Analysis}

Step 1: what is the problem: speed for installing and disassembling, which can be transferred to "time loss" in TRIZ, and safety, which can be transferred as "reliability"

Step 2: what is current solution: increase installing or disassembling time

Step 3: what are the problems for current solution: waste time and labor, delay construction work

Identify technologic contradiction: ameliorate "time loss (25)", deteriorate "reliability (27)"

Check technologic contradiction matrix table: M25$27=[10,30,4]$

Corresponding innovative principles includes:

Principle 10 - Prior Action

Principle 30 - Flexible Membranes or Thin Films

Principle 04 - Asymmetry

\section{Solutions and Innovative Outcome}

This paper uses principle 04 (i.e. asymmetry) for product design. The principle requires the object to transform from a symmetric form to an asymmetric form. If the object already has an asymmetric form, then the principle requires an increase in its 
asymmetric level. It is well accepted that engineering components can take asymmetric structures and the principle enlarges relative options. Form figure 1 it is noticeably that a traditional fixed coupler has a symmetric feature, which allows this paper to redesign it using asymmetric principle.

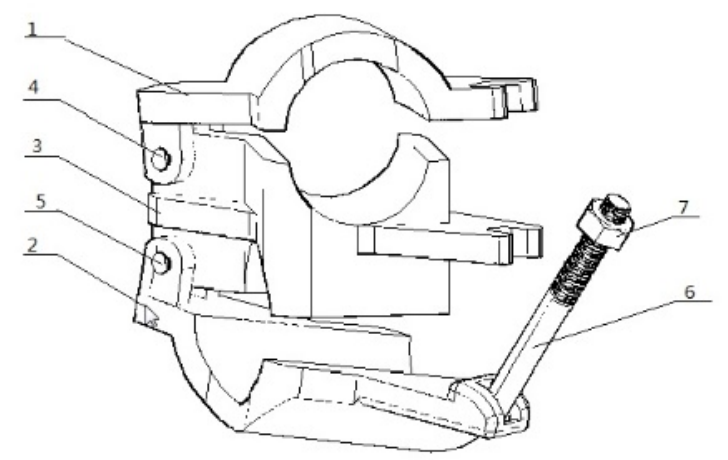

(a) Innovative coupler design

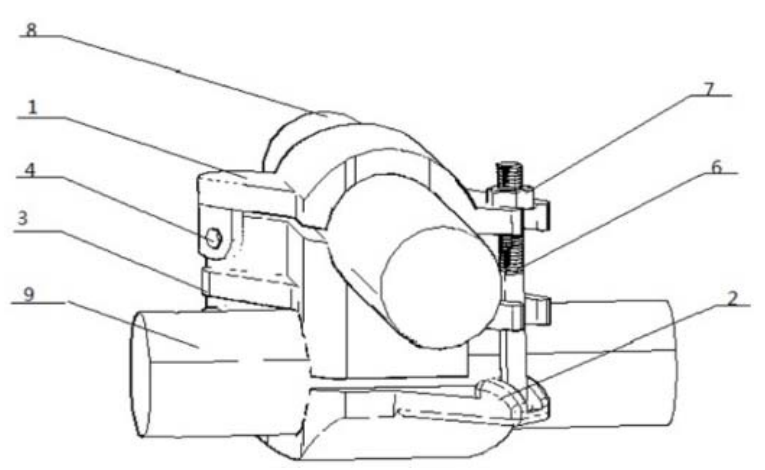

(b) Scaffolding coupler

lupper pinch plate 2 lower pinch plate 3 holder 4 upper pin 5 lower pin 6 T-bolt 7 nut 8,9 steel tubes

\section{FIGURE III. INNOVATIVE SCAFFOLDING COUPLER}

Figure 3 shows the innovative outcome based on asymmetric principle from TRIZ. In comprising with the coupler shown in figure 1, the redesigned coupler enables rapid installing and disabling and has higher safety level. Its working principle is descripted as the following. Upper pinch plate 1 and lower pinch plate 2 will connect to holder 3 and pin $(4,5)$ respectively. Upper pinch plate 1 and lower pinch plate 2 can rotate around pin 4 and pin 5 respectively. Two semi-circles of the holder are intersecting vertically with each other. Stud 6 can rotate around its lower axis.

A general product design process can be represented as in figure 4 [5] [6]:

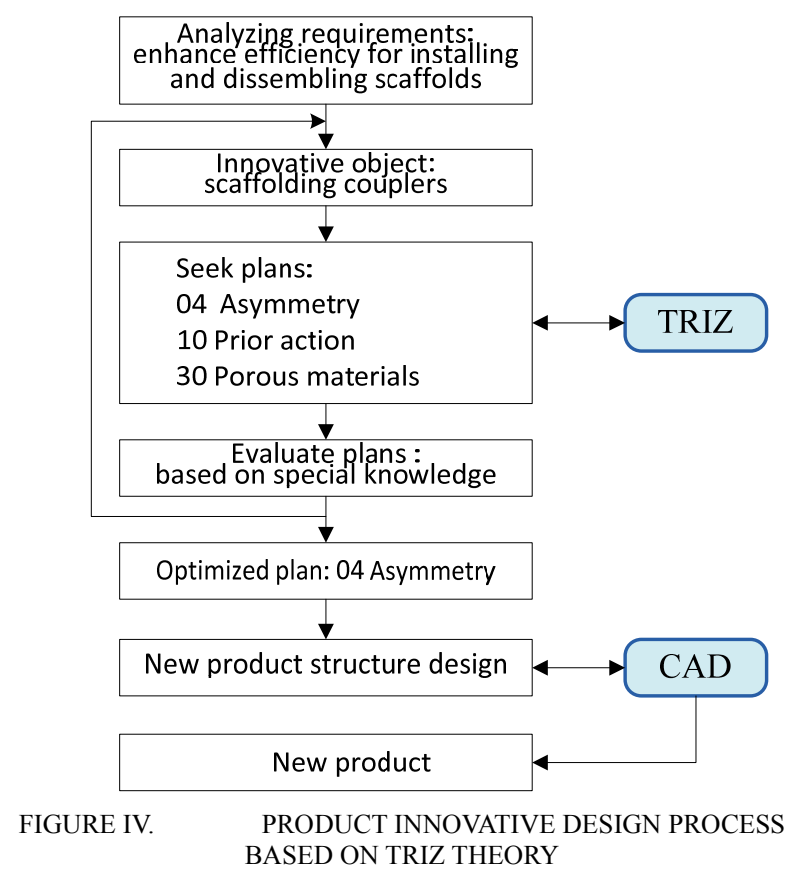

\section{E. Experimental Testing}

The redesigned scaffolding coupler in this paper reduced bolt numbers of traditional fixed coupler, and increase $50 \%$ of the installing/dissembling speed and double the relative safety level.

\section{CONCLUSION}

Fixed scaffolding coupler has become the most used structural form in China given its advantages in convenience, versatility, carrying capacity and integral rigidity. However, in quite a long period, the constructing, installing and dissembling processes of scaffolds are accompanied by safety accidents. Thus, when increasing efficiency, safety level should also be enhanced. The designed coupler in this paper has a simple structure, high stability, time saving installing and high safety level. This example showed that by catching correct technologic contradiction, it is not difficult to find a way to solve the problem based on TRIZ theory. Afterwards, a desirable solution can be obtained by proper use of special knowledge.

\section{REFERENCES}

[1] R.Tan, Innovative Design-TRIZ Invention Problem Solving Solutions[M].Beijing: China Machine Press, 2002.

[2] M.Zhang, S.Zhang, J.Lu, TRIZ Comprehensive applications analysisjournal protection and reparing[M].Beijing: China Machine Press,2012.

[3] M.Shen, TRIZ Theory and engineering innovative practice[M].Beijing: China Machine Press,2012.

[4] R.Tan, J.Ma, Z.chen, P.Jiang, Study on the process model of an oringinal innovation based on needs evolution laws of TRIZ [J]. Chinese Engineering Science,2008,10 (11):52-58.

[5] L.Wang, F.Sun, TRIZ Innovative theory and invetion principles [M].Beijing: Science Press, 2010.

[6] F.Hu, Innovative thinking developments and methods[M].Beijing: China Machine Press,200 